\title{
Development of Sustainable Eggshell Waste-Polyester Resin Composite Material for Using as Artificial Rock
}

\author{
Thaís Pereira Cunha ${ }^{a}$, Fabrício Bagli Siqueira ${ }^{a}$,José Nilson França Holanda ${ }^{a, b} *$ ib \\ ${ }^{a}$ Programa de Pós-Graduação em Engenharia e Ciência dos Materiais - PPGECM, Universidade \\ Estadual do Norte Fluminense - UENF, 28013-602, Campos dos Goytacazes, RJ, Brasil \\ ${ }^{b}$ Laboratório de Materiais Avançados - LAMAV, Universidade Estadual do Norte Fluminense - UENF, \\ 28013-602, Campos dos Goytacazes, RJ, Brasil
}

Received: December 11, 2018; Revised: August 07, 2019; Accepted: August 15, 2019

The aim of this work was to study the possibility of reuse of chicken eggshell waste produced in the food manufacturing industry for processing of sustainable eggshell waste-polyester resin composite materials for use as artificial carbonaceous rocks. For this purpose, composite specimens with different eggshell waste-polyester resin compositions in different particle sizes of the eggshell waste were prepared. The technical properties (flexural strength, water absorption, apparent porosity, and bulk density), microstructural evolution, and phase analysis of the produced composite materials were investigated. The results indicated that the composite materials containing up to $65 \mathrm{wt} . \%$ of chicken eggshell waste with flexural strength between 31.23 and $52.06 \mathrm{MPa}$, water absorption between 0.59 and 1.37 $\%$, apparent porosity between 0.99 and $2.28 \%$, and bulk density between 1.59 and $1.71 \mathrm{~g} / \mathrm{cm}^{3}$ are highly attractive for be used as sustainable artificial carbonaceous rocks in the civil construction.

Keywords: Chicken eggshell, solid waste, artificial rock, properties, microstructure.

\section{Introduction}

Brazil is one of the world's largest producers of animal protein, including chicken eggs. The Brazilian production of chicken eggs in 2016, according to ABPA (Brazilian Association of Animal Protein), achieved a new record of about 39.18 billion units ${ }^{1}$. It is important to note that almost all of this chicken egg production is destined to the domestic market $(99.57 \%)$. In addition, the main producing states of chicken eggs are: São Paulo (first), Minas Gerais (second), Espírito Santo (third), and Pernanbuco (fourth).

The main consumers of chicken eggs in Brazil are the food processing industry and homes. On the other hand, the high consumption of chicken eggs also generates a significant amount of a solid waste material called eggshell. Such a chicken eggshell waste basically comprises two main components: i) the inorganic component that corresponds to calcified eggshell that is mainly composed of calcium carbonate (calcite, $\mathrm{CaCO}_{3}$ ); and ii) the organic component that corresponds to shell membrane rich in proteins ${ }^{2,3}$. In 2016, Brazil produced about 195,000 tonnes of chicken eggshell waste. The final disposal of chicken eggshell waste is considered very difficult due to the proteinrich membrane (organic component), which can trigger urban pests (attracting rats and other vermin) ${ }^{4}$. For this reason, the reuse of chicken eggshell waste into new value-added products is of great relevance to sustainable development.
Currently, the severe environmental legislation in many parts of the world has put great pressure on companies for the final disposal of solid wastes in an environmentally sustainable manner. This scenario imposed by the environmental laws has also contributed to the development of new value-added products such as, for example, artificial rocks produced from solid wastes (marble, granite, quartz sand, glass) and polymeric resins ${ }^{5-7}$. Such artificial rocks have aroused great interest in the consumer market of ornamental rocks due to their technical and aesthetic characteristics. In fact, artificial rocks have differentiated characteristics in terms of mechanical strength, water absorption (open porosity), density, hardness, color, texture and gloss ${ }^{8}$. The industrial artificial rocks are composite materials mainly produced with about $95 \%$ of natural rock waste and $5 \%$ of resin using a vacuum vibro compression process ${ }^{5,7}$. It is important to emphasize that Brazil is one of the world's largest producers of natural ornamental rocks ${ }^{9}$. However, it has a very incipient production of artificial rocks. This situation has stimulated the development of new composite materials, preferably with polluting solid wastes for use as artificial rocks in the civil construction sector.

The aim of this work is to study the possibility of using chicken eggshell waste from food processing industry in the production of eggshell waste/resin composite materials for use as sustainable carbonaceous artificial rocks. 


\section{Materials and Methods}

\subsection{Materials}

In this study the raw materials used were chicken eggshell waste, from a food processing industry, in Campos dos Goytacazes, RJ, Brazil, and AQP 8400 preaccelerated unsaturated polyester resin, supplied by Águia Química (Lot: 46008). In addition, as hardener was used methylethylketone peroxide (PMEK).

The chicken eggshell waste sample was dried at 110 ${ }^{\circ} \mathrm{C}$ for $24 \mathrm{~h}$, crushed into powder by using a laboratory ball mill, and then sieved to three granulometric fractions: i) $<$ 60 mesh $(<250 \mu \mathrm{m})$; ii $)<100$ mesh $(<149 \mu \mathrm{m})$; and iii $)<$ 150 mesh $(<106 \mu \mathrm{m})$.

Mineralogical analysis of the eggshell waste sample was performed by X-ray diffraction (XRD-7000 model, Shimadzu) using $\mathrm{Cu}-\mathrm{K} \alpha$ radiation $(\lambda=1.5406 \AA)$ at a scanning speed of $1.5^{\circ}(2 \theta / \mathrm{min}$. ICDD-JCPDS card (PDF: 01-0837) was used to identify the calcite mineral phase. The chemical analysis of the eggshell waste was obtained using an energy-dispersive X-ray spectrometer (EDX 700, Shimadzu).

\subsection{Production of artificial rocks}

Twelve compositions of eggshell waste-polyester resin mixtures were prepared (Table 1). Initially, the polyester resin was homogenized with the hardener. Then, the eggshell waste was added and manually mixed for 5 minutes and placed into the silicone mold (size: $70 \times 20 \times 10 \mathrm{~mm}$ ). The mold was placed inside an enclosure sealed and connected to vacuum pump and placed on a vibrating table for 30 min. Finally, the hardened artificial rocks were cured in an oven at $120^{\circ} \mathrm{C}$ for $2 \mathrm{~h}$. All the artificial rocks were prepared in the Laboratory of Advanced Materials of the Northern Fluminense State University.

Table 1. Compositions of the artificial rocks (wt.\%).

\begin{tabular}{cccc}
\hline Formulation & Eggshell waste & Polyester resin & Particle size \\
\hline TC1 & 65 & 35 & $<60$ mesh \\
TC2 & 65 & 35 & $<100$ mesh \\
TC3 & 65 & 35 & $<150$ mesh \\
TC4 & 60 & 40 & $<60$ mesh \\
TC5 & 60 & 40 & $<100$ mesh \\
TC6 & 60 & 40 & $<150$ mesh \\
TC7 & 55 & 45 & $<60$ mesh \\
TC8 & 55 & 45 & $<100$ mesh \\
TC9 & 55 & 45 & $<150$ mesh \\
TC10 & 50 & 50 & $<60$ mesh \\
TC11 & 50 & 50 & $<100$ mesh \\
TC12 & 50 & 50 & $<150$ mesh \\
\hline
\end{tabular}

\subsection{Characterization of the artificial rocks}

The artificial rocks (eggshell waste-polyester resin composites) were characterized with respect to water absorption, apparent porosity, bulk density, flexural strength, $\mathrm{X}$-ray diffraction analysis, and scanning electron microscopy. All characterization tests were performed in the Laboratory of Advanced Materials of the Northern Fluminense State University.

The water absorption and apparent porosity were measured according to the standard NBR 15845/2010. The bulk density was determined according to $\mathrm{Db}=\mathrm{m} / \mathrm{Va}$, where $\mathrm{m}$ is the cured specimen mass $(\mathrm{g})$ and $\mathrm{Va}$ is the apparent volume $\left(\mathrm{cm}^{3}\right)$. The mechanical strength of the specimens was determined by a three-point bending test using an Instron universal testing machine (model 5582, Instron) at a loading rate of $0.5 \mathrm{~mm} /$ min, according to the standard ASTM C-674/77.

Cured specimens were analyzed for mineralogical characterization by X-ray diffraction (XRD-7000 model, Shimadzu) using $\mathrm{Cu}-\mathrm{K} \alpha$ radiation. The microstructure of the fractured surfaces of cured specimens was observed by means of secondary electron images using a Shimadzu SSX-550 SEM, at $15 \mathrm{kV}$, after platinum coating.

\section{Results and Discussion}

\subsection{Characteristics of the waste}

The X-ray diffraction pattern of the chicken eggshell waste sample is shown in Figure 1. The chicken eggshell waste in form of fine powder is essentially composed of rhombohedral structured calcite $\left(\mathrm{CaCO}_{3}\right.$; PDF: 01-0837) with unit cell parameters $\mathrm{a}=4.983 \AA, \mathrm{c}=17.019 \AA$, and R3c (167) space group.

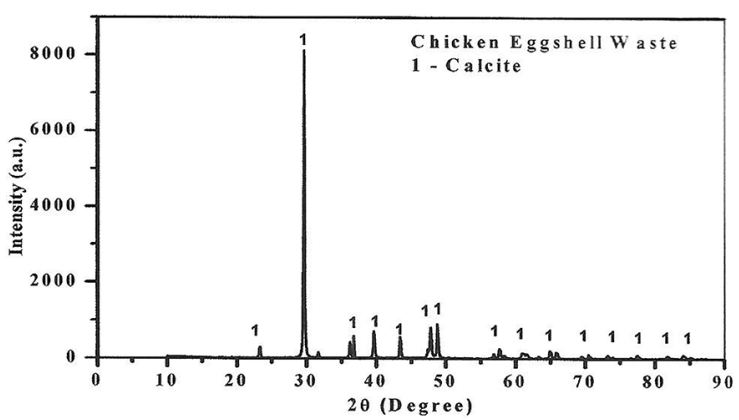

Figure 1. X-ray diffraction pattern of the eggshell waste sample.

The chemical analysis of the chicken eggshell waste sample is given in Table 2 . It can be seen that the chicken eggshell waste sample presented a high amount of calcium oxide $(\mathrm{CaO})$ with 97.12 wt.\% and small amounts of potassium oxide $\left(\mathrm{K}_{2} \mathrm{O}\right)$, sulfur oxide $\left(\mathrm{SO}_{3}\right)$, strontium oxide $(\mathrm{SrO})$, and zirconium oxide $(\mathrm{ZrO} 2)$. 
This result is in agreements with the X-ray diffraction analysis (Figure 1). In addition, the chicken eggshell waste sample can be considered a pure relatively natural carbonate material, whose its composition is very similar to the calcitic calcareous ${ }^{10}$.

Table 2. Chemical analysis of eggshell waste.

\begin{tabular}{cc}
\hline Oxides & Wt.\% \\
\hline $\mathrm{CaO}$ & 97.12 \\
$\mathrm{~K}_{2} \mathrm{O}$ & 1.39 \\
$\mathrm{SO}_{3}$ & 1.16 \\
$\mathrm{SrO}$ & 0.14 \\
$\mathrm{ZrO}_{2}$ & 0.19 \\
\hline
\end{tabular}

\subsection{Phase analysis and microstructure}

The X-ray diffraction patterns of the cured artificial rocks are shown in figures 2 and 3 . Note that all the diffractograms presented an amorphous band characteristic of the polyester resin and diffraction peaks characteristic of calcite. The peaks of calcite are due to the chicken eggshell waste used. Note also that only small differences in the peak intensities occurred.

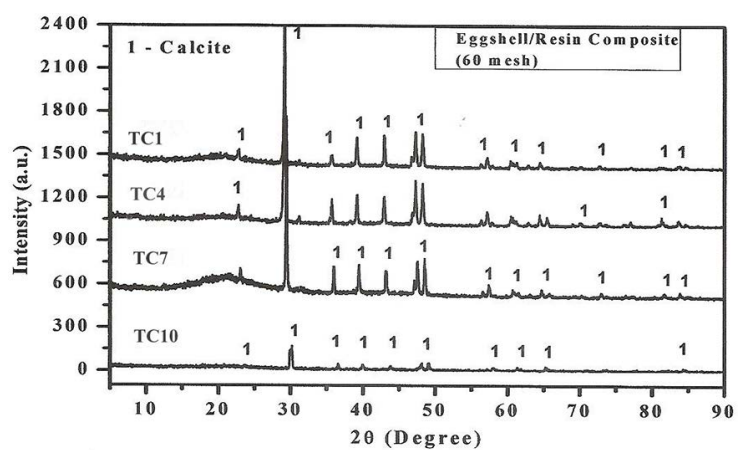

Figure 2. X-ray diffraction pattern of the artificial rocks produced with chicken eggshell waste $(<60$ mesh).

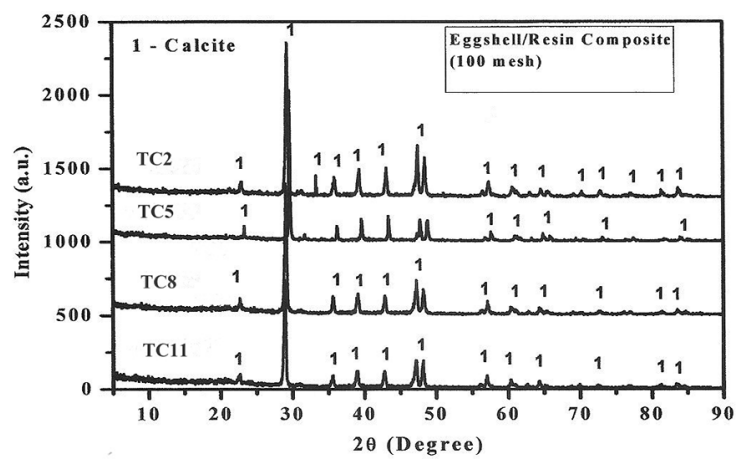

Figure 3. X-ray diffraction pattern of the artificial rocks produced with chicken eggshell waste $(<100 \mathrm{mesh})$.
SEM micrographs of the fractured surfaces of the cured specimens are shown in figures 4-6. It can be seen that the microstructure of the cured specimens showed no cracks. However, all the formulations tested presented bubbles originated from the resin, as well as several pores. The main reason for the presence of bubbles and pores was the nonuse of a vacuum vibro compression process. Despite this, smooth fracture surfaces and good degree of densification of the specimens occurred. The results also indicated that the use of chicken eggshell waste with finer particle sizes (100 and 150 mesh) tend to favor the obtaining of fracture surfaces more homogeneous with smaller amounts of bubbles and pores. This fact shows that the smaller the particle size of chicken eggshell waste, the more efficient the wetting and adhesion of the chicken eggshell waste by the resin. Such an adhesion results in good interface characteristics in the produced artificial rocks.

\subsection{Properties of artificial rocks}

Figure 7 shows the flexural strength values of the specimens as a function of the eggshell waste-polyester resin composition and particle size of the chicken eggshell waste used. It can be seen that the values of flexural strength of the specimens lie in the range of 31.23 to $52.06 \mathrm{MPa}$. These values of mechanical strength are very important, since they characterize the artificial rocks produced as being of high mechanical strength $(>20 \mathrm{MPa})^{11}$. It is also noted that in general the specimens produced using eggshell waste with finer particle size (100 mesh and 150 mesh) tend to have higher mechanical strength values. Such a behavior is due to the better interfacial adhesion in these composite materials.

The water absorption values of the test specimens as a function of the composition and particle size of the chicken eggshell waste are shown in Figure 8. Water absorption is an important physical property used as one of the parameters to determine the technical quality of natural and artificial rocks. It is directly related to the level of open porosity of the specimens. For the studied conditions, it was established that the artificial rocks had values of water absorption in the range of $0.59-1.37 \%$. Thus, most of the artificial rocks produced can be classified as being of medium water absorption ${ }^{11}$. The correlation between the values of water absorption and flexural strength is well established. As can be observed in Figure 8, in general, the specimens produced using eggshell waste with finer particle size (100 mesh and 150 mesh) tend to have lower water absorption values. The apparent porosity values ( $0.99-2.28 \%)$, as shown in Figure 9, followed a behavior very similar to those of water absorption. 

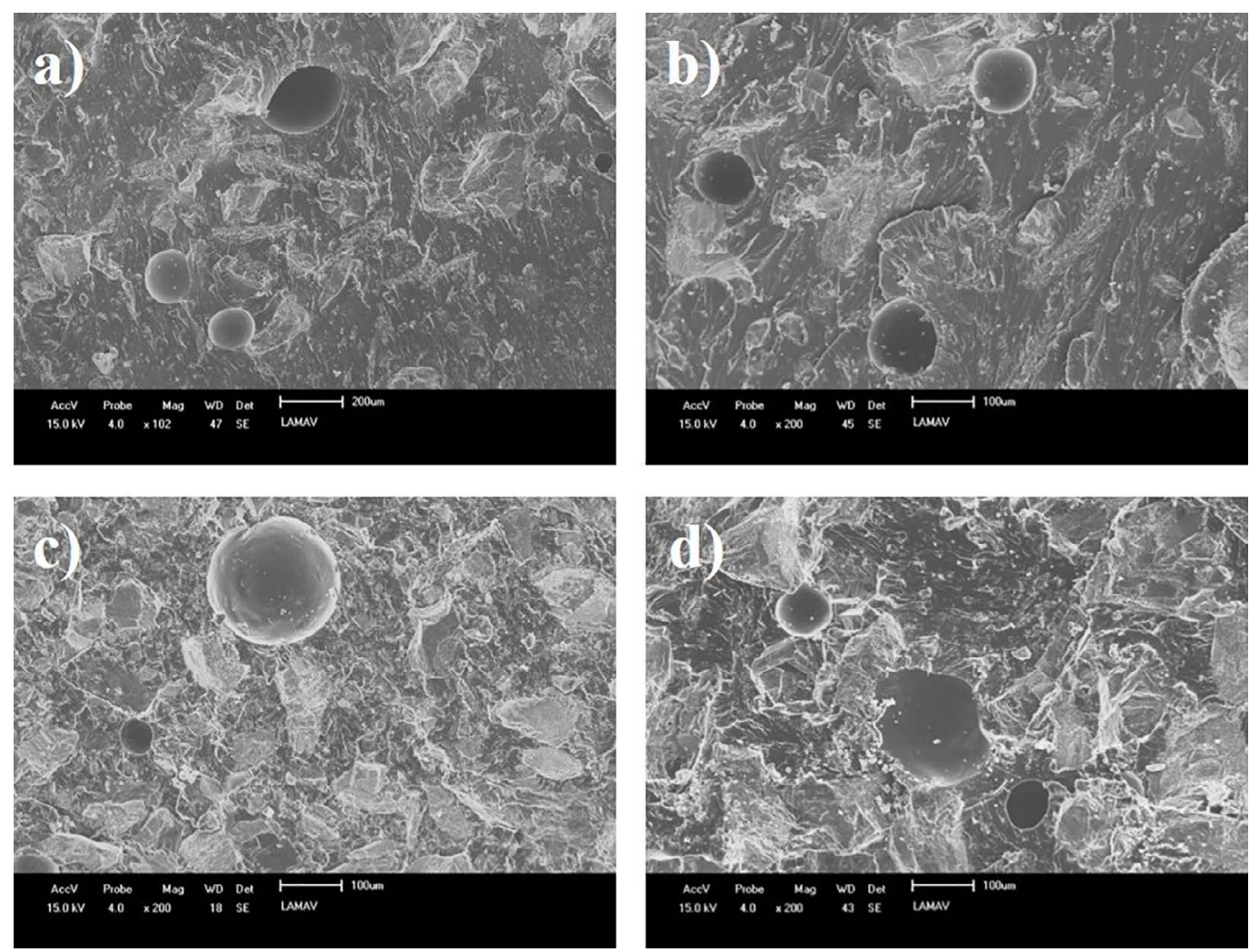

Figure 4. SEM micrographs of the artificial rocks produced with chicken eggshell waste (<60 mesh): a) 50/50; b) 55/45; c) $60 / 40$; and d) $65 / 35$.
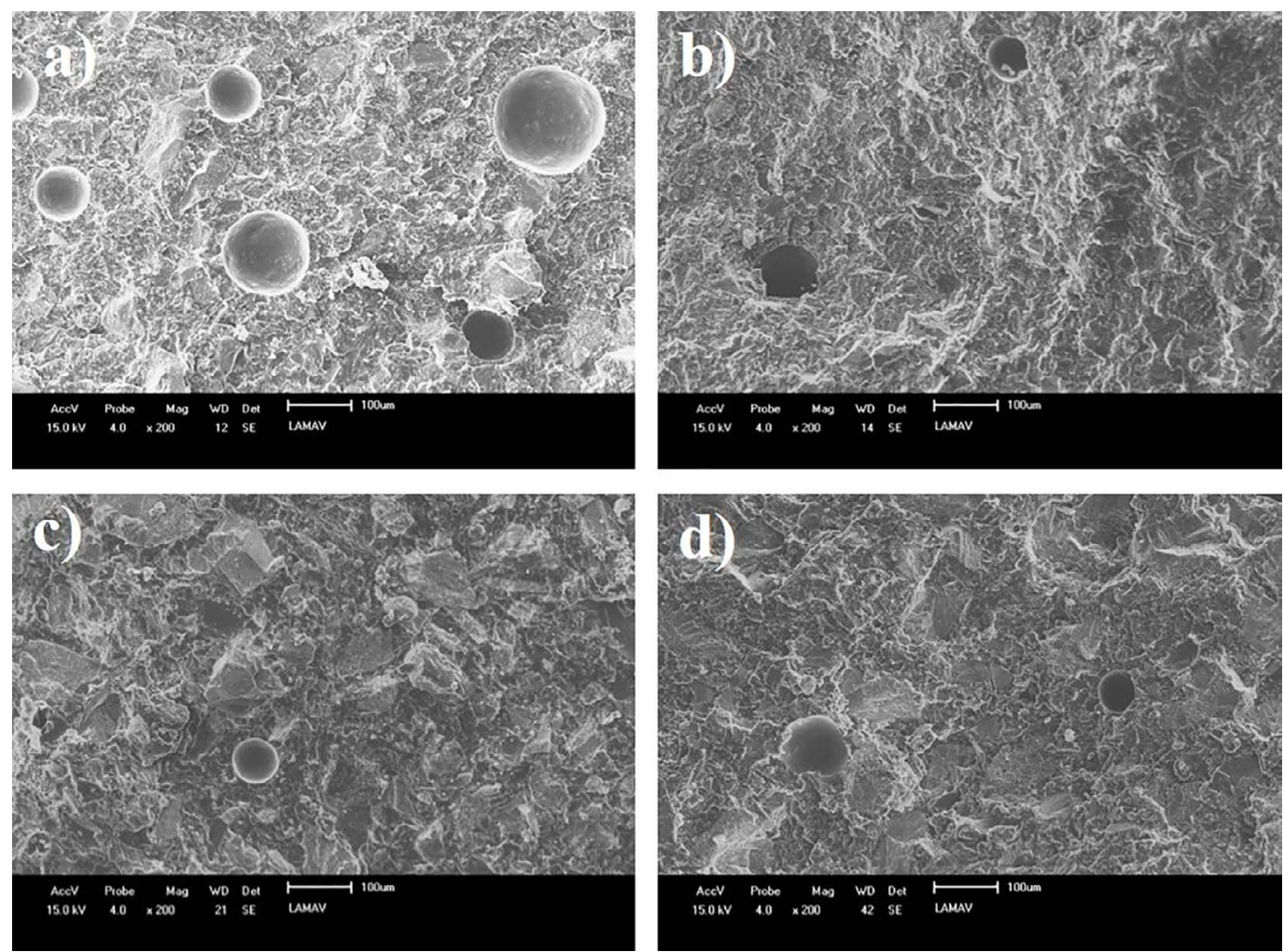

Figure 5. SEM micrographs of the artificial rocks produced with chicken eggshell waste (<100 mesh): a) 50/50; b) $55 / 45$; c) $60 / 40$; and d) $65 / 35$. 

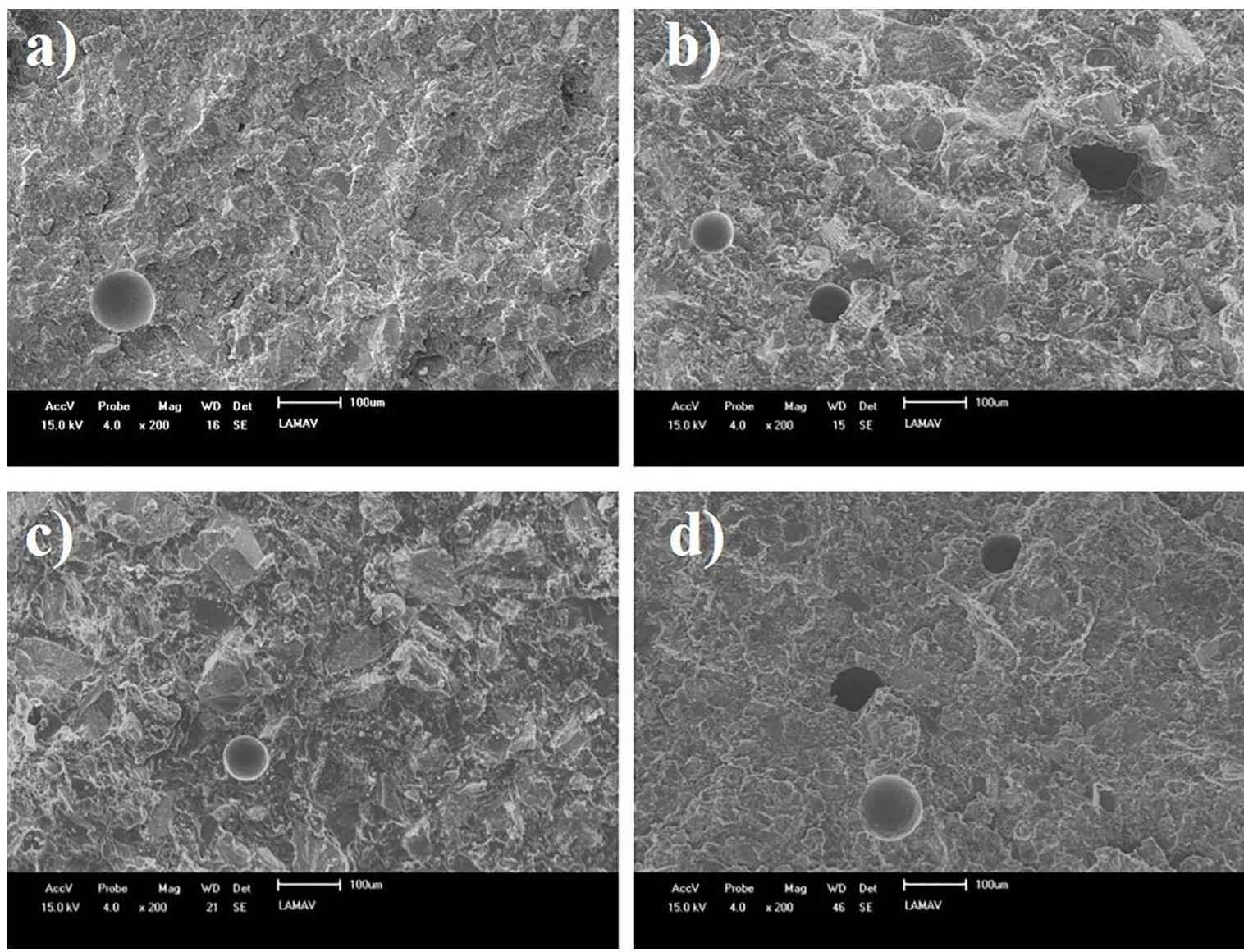

Figure 6. SEM micrographs of the artificial rocks produced with chicken eggshell waste ( $<150$ mesh): a) 50/50; b) 55/45; c) 60/40; and d) 65/35

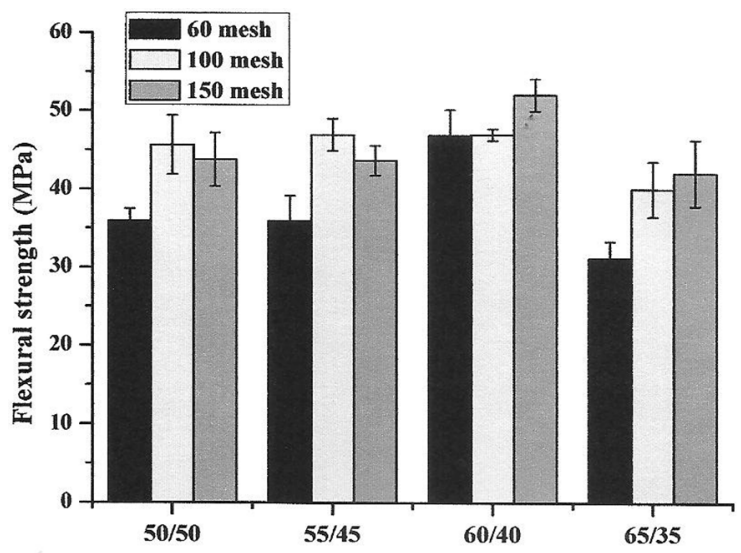

Eggshell waste/Resin Composite

Figure 7. Flexural strength of the cured artificial rock specimens.

The bulk density values of the artificial rocks produced are shown in Figure 10. The results showed that the bulk density values are higher for the waste-polyester resin composites with higher amount of chicken eggshell waste. This is related to the higher density value of the chicken eggshell waste $\left(2.41 \mathrm{~g} / \mathrm{cm}^{3}\right)$, which is the reinforcing component with respect to the polyester resin (matrix) used.

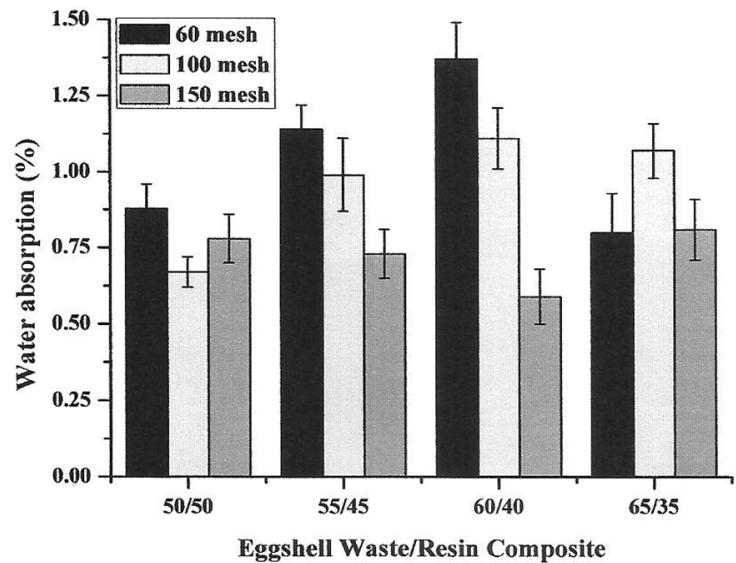

Figure 8. Water absorption of the cured artificial rock specimens.

Note also that the specimens prepared with finer particle size of eggshell waste ( 100 mesh and 150 mesh) tend to be slightly denser. The bulk density values found in the range from 1.59 to $1.71 \mathrm{~g} / \mathrm{cm}^{3}$ are lower than those of natural carbonaceous rocks, such as marbles $\left(2.31-2.80 \mathrm{~g} / \mathrm{cm}^{3}\right)^{12}$. This is important because the artificial rocks produced with chicken eggshell waste are lighter than the natural carbonaceous rocks normally used in the civil construction industry. 


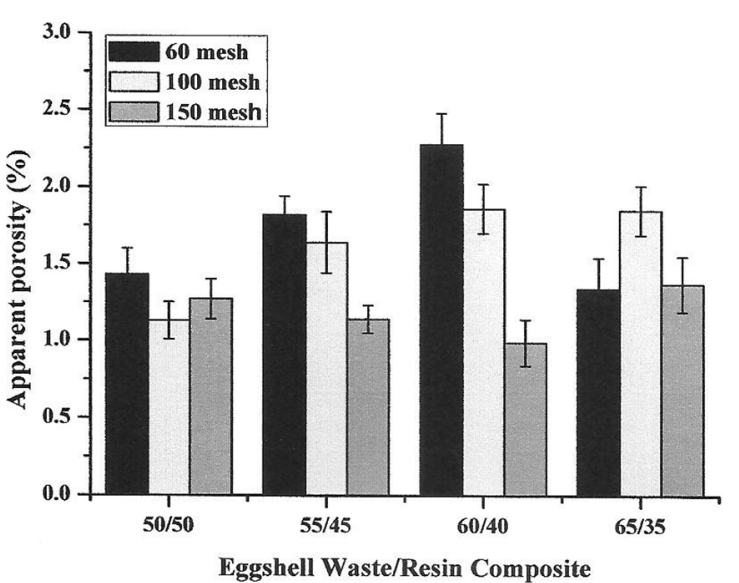

Figure 9. Apparent porosity of the cured artificial rock specimens.

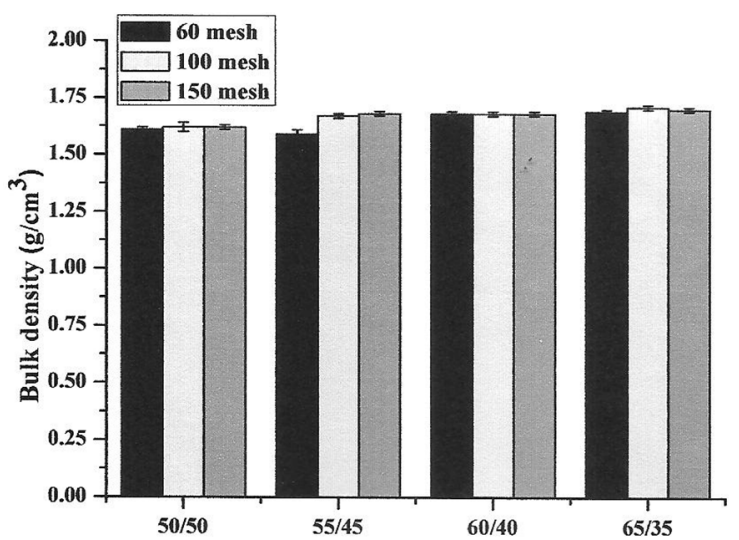

Eggshell Waste/Resin Composite

Figure 10. Bulk density the cured artificial rock specimens.

\section{Conclusions}

The results of this work demonstrated that the use of chicken eggshell waste as alternative carbonate material (rich in $\mathrm{CaCO}_{3}$, calcite) for the production of artificial rocks seems to be a viable way for final disposal of this abundant solid waste. X-ray diffraction analysis indicated that all artificial rocks produced are characterized as being eggshell waste/ polyester resin composite materials. SEM micrographs showed a compact matrix with good interfacial adhesion in the artificial rocks. The results of the present study suggest that chicken eggshell waste/polyester resin composites containing up to $65 \mathrm{wt}$.\% of chicken eggshell waste with distinct particle sizes (100 mesh and 150 mesh) could be used as sustainable artificial carbonaceous rocks with good technical properties for application in the civil construction.

\section{Acknowledgements}

The authors acknowledge the Foundation for Research Support of the State of Rio de Janeiro - Brasil (FAPERJ) - Process No. E-26/203.013/2016; and National Council for Scientific and Technological Development - Brasil (CNPq) - Process No. 305928/2016-3 for supporting this work.

\section{References}

1. Associação Brasileira de Proteína Animal (ABPA). Relatório Anual da ABPA 2017. São Paulo: ABPA; 2017.

2. Parsons AH. Structure of the eggshell. Poultry Science. 1982;61(10):2013-2021.

3. King'ori AM. A review of the uses of poultry eggshells and shell membranes. International Journal of Poultry Science. 2011;10(11):908-912.

4. Amaral MC, Siqueira FB, Destefani AZ, Holanda JNFH. Soildement bricks incorporated with eggshell waste. Waste and Resource Management. 2013;166(WR3):137-141.

5. Lee MY, Ko CH, Chang FC, Lo SL, Lin JD, Shan MY, Lee JC. Artificial stone slab production using waste glass, stone fragments and vacuum vibratory compaction. Cement and Concrete Composites. 2008;30(7):583-587.

6. Ribeiro CEG. Produção de Rocha Artificial utilizando resíduo da indústria de mármore em matriz poliéster. [Dissertation]. Campos dos Goytacazes: Universidade Estadual do Norte Fluminense Darcy Ribeiro; 2011.

7. Silva FS, Ribeiro CEG, Rodriguez RJS. Physical and mechanical characterization of artificial stone with marble calcite waste and epoxy resin. Materials Research. 2018;21(1):e20160377.

8. Bera P, Guptha N, Dasan KP, Natarajan R. Recent developments in synthetic marble processing. Reviews on Advanced Materials Science. 2012;32(2):94-105.

9. Montani C. XXVIII Relatório mármore e rochas no mundo 2017 - Dossiê Brasil. São Paulo (SP): ABIROCHAS; 2017.

10. Freire MN, Holanda JNF. Characterization of avian eggshell waste aiming its use in a ceramic wall tile. Cerâmica. 2006;52(324):240-244.

11. Chiori Filho C, Rodrigues EP. Guia de aplicação de rochas em revestimentos. São Paulo (SP): ABIROCHAS; 2009.

12. Menezes RG, Larizzatti JH. Rochas ornamentais e de revestimentos: conceitos, tipos e caracterização tecnológica. Rio de Janeiro (RJ): DG/UFRJ; 2005. 